\title{
Direct economic benefits and human dependence toward Gunung Merapi National Park, Indonesia
}

\author{
RUKY UMAYA ${ }^{1, \nu}$, HARDJANTO ${ }^{1, v \vee}$, RINEKSO SOEKMADI ${ }^{2}$, SATYAWAN SUNITO ${ }^{3}$ \\ ${ }^{1}$ Department of Forest Management Science, Faculty of Forestry, Institut Pertanian Bogor. Jl. Lingkar Akademik, Dramaga, Bogor 16680, West Java, \\ Indonesia. Tel./fax.:+62-251-862-6806, ^email: asistara@yahoo.com; ^vhardjanto@ gmail.com \\ ${ }^{2}$ Department of Forest Resource Conservation and Ecotourism, Faculty of Forestry, Institut Pertanian Bogor. Jl. Lingkar Akademik, Dramaga, Bogor \\ 16680, West Java, Indonesia \\ ${ }^{3}$ Department of Communication Science and Community Development, Faculty of Human Ecology, Institut Pertanian Bogor. Jl. Kamper, Dramaga, \\ Bogor 16680, West Java, Indonesia
}

Manuscript received: 10 November 2019. Revision accepted: 9 February 2020.

\begin{abstract}
Umaya R, Hardjanto, Soekmadi R, Sunito S. 2020. Direct economic benefits and human dependence toward Gunung Merapi National Park, Indonesia. Biodiversitas 21: 982-993. Merapi (Java, Indonesia) is recognized as the most active volcano in Indonesia. This area has also gazetted as a national park, called Gunung Merapi National Park (GNMP), despite the existence of humans who live adjacent to the park with high dependency on its resources. The objectives of this study were to determine direct use value (DUV) and investigate human dependence toward the goods and services generated from GNMP. The research was conducted in 27 sub-villages. In total 277 respondents and 62 key informants were selected using purposive sampling and 9 times focus group discussion. The DUV was estimated using market price approach. The results of this study found that the DUV of GMNP was IDR 87,947,589,505 year ${ }^{-1}$, generated from direct benefit of grasses for animal feedstock (41.74\%), sand mining (31.32\%), water consumption (20.23\%), fuelwood collection (3.57\%), ecotourism activities (1.65\%), land management for agriculture (1.48\%), and orchid conservation program (0.01\%). The dominance of DUV derived from grasses collection, sand mining and water consumption was highly correlated with the characteristics of sub-villages communities, influenced by the events of eruption of Merapi volcano, changes in legal status of forest function and market situations. Sub-village communities have historically developed reciprocal relationships with Merapi volcano and its surrounding ecosystem in terms of ecological, economic, and cultural aspects, and they played important roles in natural resources management of Merapi volcano. The findings of this study suggest that an important strategy for GMNP authority is by positioning subvillage communities and their norms as resource beneficiaries and partners in managing the park, highlighting that their existence should not be neglected.
\end{abstract}

Keywords: Adaptation, dependence, direct use value, national park, sub-village

\section{INTRODUCTION}

Merapi volcano is located in the center of Java Island and it is administratively located in the provinces of Special Region of Yogyakarta and Central Java. It is considered as one of the most active and hazardous volcanoes in the world (Voight et al. 2000; Surono et al. 2012) which has erupted 61 times since the $15^{\text {th }}$ Century with average cycle of eruption of 3.5 years (Thouret et al. 2000). The eruption in 2010 is considered as the biggest eruption event since the last 140 years (Subandriyo et al. 2014).

The areas surrounding Merapi volcano are mostly state forest categorized as montane ecosystem. Since 2004, the areas around Merapi volcano have been gazetted as conservation areas in the form of national park through the decree of the Minister of Forestry Number 134/KptsII/2004 and named as Gunung Merapi National Park (GMNP). Besides the existence of the national park, the areas adjacent to the park are densely populated with 400,000 people with relatively high risk to pyroclastic flows, surges, and lahars (Thouret et al. 2000). Merapi volcano is surrounded by 71 sub-village communities who live adjacent to forest boundaries with high dependency on the national park (BTNGM 2017), reflecting a close relationship between natural/ecological and social systems. People and environments need to considered together, as social and ecological subsystems that are linked by mutual feedbacks, and are interdependent and co-evolutionary (Folke et al. 2003, Budiharta et al. 2016, Berkes 2017). The human relationships with social and natural systems can form wise management of natural resources (often called local wisdom) or conversely can result in severe exploitation (Newton et al. 2016; Dharmawan 2007; Akyol et al. 2017; Iskandar et al. 2017).

Forest resources are economically beneficial to local communities (McNeelly 1994, Pearce and Moran 1994, Iskandar et al. 2016). In particular, montane forest provides ecosystem goods and services to communities (Pratt and Preston 1998; IUCN 2004; Ives et al. 2004). An understanding of economic value is enormously required in making policies as well as in altering individual and collective choices in the management and utilization of natural resources and creating sustainable environment (Daily et al. 2009). The economic valuation of natural resources is an effort to add quantitative measures of the goods and services provided by ecosystem (Pearce 2001; Turner et al. 2004; Anna and Saputra 2017; Rizal and Dewanti 2017). Direct use value (DUV) is a value of direct 
benefits generated from natural resources (Pearce 2001). In Gunung Merapi National Park, the local communities adjacent to the area might gain benefits from grasses for animal feedstock, sand mining, water provision, firewood collection, land, orchid, and tourism.

The interrelationship between social system and natural system makes communities have the ability to manage and utilize the resources available (Rambo 1983; Marten 2001; Newton et al. 2016). In Gunung Merapi National Park, the local communities are mostly Javanese ethnic who traditionally have strong connection with nature, including volcano, river, trees and all its resources (Triyoga 2010). Their abilities to survive lead them to develop a way of life where they can adapt to the area prone to disaster (Hudayana 1994; Lavigne et al. 2008). They also develop a strong dependence on the forest area where they make a close connection in the dimension of ecological, economic, and cultural. The strong dependence and connection of local communities to Merapi volcano and the surrounding forest reflects that socio-economic and cultural aspects are fundamental principle that unites the lives of communities.

Natural resources in GMNP are the most important goods and services for the local communities for subsistence and commercial purposes. Based on regulation, Minister of Forestry decree number 56 of 2006 concerning zoning renewed Minister of Environment and Forestry number 76 of 2015, local communities are permitted to utilize natural resources generated from the national park within the traditional zone, specific zone, and utilization zone. Nonetheless, the communities, as well as local goverments, tend to lack understanding of the benefits of the national park (Daily et al. 2009; Setiyani et al. 2017). As a consequence, conservation efforts involving beneficiaries of resources have not been optimal (Widada 2004; Helida 2016; Roslinda et al. 2017; Roslinda 2019). Therefore, it is necessary to implement sustainable natural resources utilization of GMNP according to its ecosystem and human dependence characteristics.

Previous studies related to Direct Use Value (DUV) in GMNP showed that economic value of recreation activities at Kaliurang natural forest was IDR 31.2 billion (Dewanta 2010) while Setiyani et al. (2017) stated that afforestation scenario at Kali Kuning watershed presented the highest economic value with USD 1.8 billion and the GMNP authority estimated the economic values of grass, water and fuelwood was IDR 25.94 billion year $^{-1}$ (BTNGM 2017). Despite these important studies, there is a lack of comprehensive research that integrate all resources in GMNP into total direct use value, hindering the authority to optimize cooperation with beneficiaries. So that this study is necessary to determine the total DUV and investigate the characteristics of human dependence toward GNMP.

\section{MATERIALS AND METHODS}

\section{Study period and area}

The research was carried out from August 2017 to December 2018. The study area was located in 27 subvillage (hamlet) communities who live adjacent to GMNP. Sub-village is the smallest community in Java as a living environment and habitat for Javanese (Hudayana 1994; LAURA 2012). In total, there were 71 sub-villages of local communities located on the highest slopes of Merapi volcano, spread in 30 villages, 7 sub-districts, 4 districts (Sleman, Magelang, Boyolali, and Klaten) and 2 provinces (Special Region of Yogyakarta and Central Java). The geographical coordinates ranged from $110^{\circ} 19^{\prime} 0^{\prime \prime} \mathrm{E}$ $110^{\circ} 30^{\prime} 0^{\prime \prime} \mathrm{E}$ and $7^{\circ} 30^{\prime} 0^{\prime \prime} \mathrm{S}-7^{\circ} 37^{\prime} 0^{\prime \prime} \mathrm{S}$ (Figure 1). These communities live at 600-1,700 meters above sea level and are famous for their agriculture resources management systems as well as their distinctive livestock system.
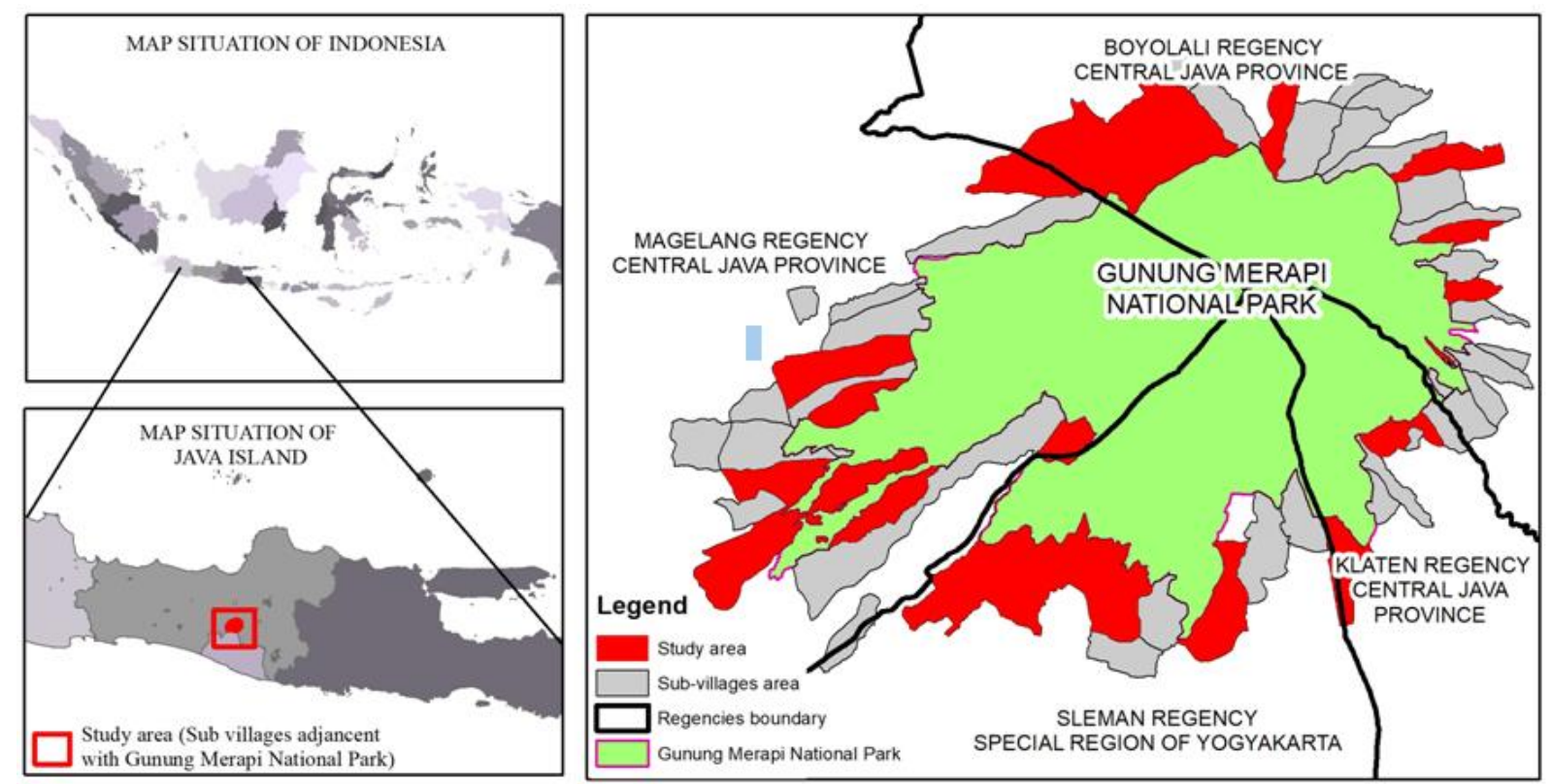

Figure 1. Research site in 27 sub-villages communities adjacent to Gunung Merapi National Park, Java, Indonesia 


\section{Procedures}

The research was conducted using a combination of interview, field observation, focus group discussion and literature review. Purposive sampling was used to represent the diversity of communities. Sub-villages were selected based on history of eruption, shifting of forest function, and market demands. Respondents were purposively selected from members of the 27 sub-villages and the peoples who got direct benefits from GMNP (e.g. grass and animal fodder, sand mining, water, fuelwood, tourism, land, and orchid. Data and information were collected by interviewing the respondents using structured questionnaires and open questionnaires. Some questions asked to respondents were kind of resources utilized from GMNP, frequency to utilize the resources, characteristic of natural resources and history of acquisition. Deep interview was conducted by snow-ball sampling to key informants. Field observation was conducted for ten months. Focus group discussion (FGD) was carried out 9 times between GMNP authority and resources beneficiaries to discuss history and regulation of sustainable resource utilization. Secondary data were obtained from the literature, reports and other documents related to the study.

\section{Data analysis}

Analysis of economic value was restricted to Direct Use Value (DUV). DUV is a value of benefits directly generated from resources, arising from consumptive and non-consumptive uses of the forest (e.g. timber and fuelwood, extraction of genetic materials and tourism) (Pearce 2001). The market price was used to determine the size of DUV and set based on the market transaction (Davis and Johnson 1987). The characteristics of human dependence to GMNP were analyzed qualitatively. The analysis of culture was carried out to investigate the dependency of communities in the 27 sub-villages according to the results of social situations (places, actors and activities).

\section{RESULTS AND DISCUSSION}

Gunung Merapi National Park has volcano ecosystem, natural mountain scenery, and traditional communities as well as local people's culture. The entire slopes of Merapi volcano can be accessible and livable as human settlements at altitudes of 600-1,700 above sea level. The combined data of BTNGM (2017) and this study showed that communities that got benefits from GMNP consist of 4,242 households $(\mathrm{HH})$ spread in 70 sub-villages utilizing grass and animal fodder; 3,369 $\mathrm{HH}$ of water users spread in 66 sub-villages; $1,635 \mathrm{HH}$ of fuelwood users in 60 subvillages; $626 \mathrm{HH}$ got economic benefits from tourism activities; $95 \mathrm{HH}$ of land users in 3 sub-villages and $10 \mathrm{HH}$ orchid groups in 1 sub-village.
Total direct use value of Gunung Merapi National Park

This study estimated the total DUV of GMNP generated from seven resources (i.e. grass/animal fodder, water, sand mining, fuelwood, land, tourism, and orchid) was IDR $87,947,589,505$ year $^{1}$ (Table 2). The highest economic value (93.29\% of total DUV) was contributed by the benefits generated from grass/animal fodder $(41.74 \%)$, sand mining $(31.32 \%)$ and water $(20.23 \%)$. The importance of these three resources can give information for the GMNP authority in making commitment to the beneficiaries. In addition to DUV, the number of beneficiaries, distribution, and history of utilization can determine the influence of GMNP, and vice versa.

Despite ranked fifth, tourism activities outside the park is important to note because when the direct impact on communities adjacent to GMNP was taken into consideration, it had a higher economic value than grass. Water and sand were two resources inside GMNP that can be utilized outside of GMNP area. However, the value of water and sand calculated in this study was restricted only to those inside GMNP. If the value of water and sand outside the park were also calculated, it will extremely higher than all resources.

The DUV of grasses/animal fodder was IDR $36,713,017,250$ which was derived from 2,004,436 bunches of grasses collected from the national park (Table 3 ). The grasses collected by 4,642 $\mathrm{HH}$ were scattered all over the slopes of GMNP. During the dry season, the price of grasses varied between IDR 10,000 to IDR 30,000 per bunch or IDR 17,500 at average price. The frequency of the grass collection can be divided into two types: once per day (to feed 1-2 cattle) and two times per day (to feed 3-5 cattle). The feeding needs of cattle was approximately 30 $40 \mathrm{~kg}$ of grasses/fodder with additional concentrate feeding. During the dry season, all respondents stated that they collected grasses from GMNP, while during the rainy season $91 \%$ of respondents collected grasses from GMNP and the rest $(9 \%)$ collected grasses from their own land. This result showed higher value than preliminary study conducted by GMNP authority that estimated DUV from grass was IDR 19.4 billion. The difference in value is likely due to the different approach of method in calculating the grasses needed and market prices.

The DUV of sand mining was IDR 27,541,500,000 which was derived from 26,230 trucks per year (Table 4). There were 1,320 of $\mathrm{HH}$ who relied on one mining source in Sungai Putih called Jurang Jero which have high benefits from sand. The activity of sand mining had been carried out by communities who lived surrounding Jurang Jero from generations. Since 2015, they committed to restrict the activities by allowing only one truck per day from Monday to Friday with the owners of the trucks that were restricted to sub-village communities. The data showed that the average frequency of trucks per day was 133 . The price of sand varied between IDR 120,000 to IDR 130,000 per $\mathrm{m}^{3}$, as such the average price was IDR $1,050,000$ per truck. 
Table 2. Total direct use value of Gunung Merapi National Park, Indonesia

\begin{tabular}{llc}
\hline Name of resource & Direct economic value (IDR/year) & Percentage \\
\hline Grasses/animal fodder & $36,713,017,250$ & 41.74 \\
Sand & $27,541,500,000$ & 31.32 \\
Water (for non-commercial and commercial users) & $17,789,944,755$ & 20.23 \\
Fuel wood & $3,139,200,000$ & 3.57 \\
Tourism & $1,453,097,500$ & 1.65 \\
Land (agroforestry) & $1,301,580,000$ & 1.48 \\
Orchid & $9,250,000$ & 0.01 \\
Total & $87,947,589,505$ & 100 \\
\hline
\end{tabular}

Table 3. Direct use value of grasses in Gunung Merapi National Park, Indonesia

\begin{tabular}{lcccccc}
\hline $\begin{array}{c}\text { Frequency of } \\
\text { collection per day }\end{array}$ & Beneficiaries & Need/day & Need/year & Unit & Price/bunch & Value/year \\
\hline 1 & $3,249 \mathrm{HH}$ & 3,249 & $1,129,417$ & Bunch & 17,500 & $19,764,804,150$ \\
2 & $1,393 \mathrm{HH}$ & 2,786 & 968,469 & Bunch & 17,500 & $16,948,213,100$ \\
\multicolumn{7}{l}{} \\
\hline
\end{tabular}

Note: Frequency of collection per day: once per day for 1-2 cattle; twice per day for 3-5 cattle

Table 4. Direct use value of sand mining in Gunung Merapi National Park, Indonesia

\begin{tabular}{llllll}
\hline Beneficiaries & Product/day & Product/years & Unit & Price/truck & Value/year \\
\hline $1,320 \mathrm{HH}(220$ drivers \&1,100 labours) & 133 & 26,230 & Truck & $1,050,000$ & $27,541,500,000$ \\
\hline
\end{tabular}

Table 5. Direct use value of water in Gunung Merapi National Park, Indonesia

\begin{tabular}{lccrrr}
\hline \multicolumn{1}{c}{ Beneficiaries } & Consumption/day* & Consumption/years & Unit & $\begin{array}{l}\text { Price } \\
\text { (IDR) }\end{array}$ & Value (IDR)/year \\
\hline 1. Non-commercial (3,369 HH) & $3,032.1$ & $1,106,716.5$ & $\mathrm{~m}^{3}$ & 2,650 & $2,932,798,725$ \\
2. Commercial & & & & \\
PDAM Tirta Marta Yogyakarta & $6,378.9$ & $2,328,302.8$ & $\mathrm{~m}^{3}$ & 2,650 & $6,170,002,950$ \\
PDAM Tirta Dharma Sleman & $7,836.5$ & $2,860,315.2$ & $\mathrm{~m}^{3}$ & 2,650 & $7,579,835,280$ \\
PT. Anindya Mitra Internasional & $1,144.8$ & $416,707.2$ & $\mathrm{~m}^{3}$ & 2,650 & $1,107,307,800$ \\
Total & & & & & \\
\hline
\end{tabular}

Note: *Consumption: $0.9 \mathrm{~m}^{3}$ day $^{-1}$ (Household user for non-commercial consumption)

This study showed the DUV of water consumption was IDR 17,789,944,755 based on commercial and noncommercial users (Table 5). Non-commercial water consumption was $1,106,717 \mathrm{~m}^{3}$ year $^{-1}$ utilized by $3,369 \mathrm{HH}$ scattered around the western, southern, and southeastern parts of GMNP. The needs of water for every HH was 0.9 $\mathrm{m}^{3} \mathrm{day}^{-1}$. Commercial water consumption used by private parties was $5,606,470,080 \mathrm{~m}^{3} \mathrm{year}^{-1}$ where it relied only on Umbul Temanten. In addition to DUV of water, there was also utilization outside GMNP for agricultural and livestock irrigation around the area. This value is likely extremely higher, considering the large volume of water flowing out in the western and southern slope of the GMNP. The DUV from two water sources (i.e. Umbul Temanten and Blongkeng River) that flow to outside the GMNP for agriculture and livestock farming was estimated to reach IDR 131 billion.

The DUV of tourism inside GMNP was IDR $1,453,097,500$ which was derived from 7 tourism gates
(IDR 1,255,097,500) and community incomes generated from mountain guiding and basecamp organizing (IDR 198,000,000). The non-state tax revenue in the form of ticket fee cost the visitors IDR 5,000 on the weekdays and IDR 7,500 on the weekend. The direct economic contribution of GMNP from tourism activities outside the GMNP was estimated IDR 72,912,325,850 generated from various activities run by the communities living adjacent to GMNP. The incomes were generated from five sources: (i) Food sellers and souvenir stalls around Kaliurang bus station; (ii) Jeep communities at Kaliurang and Cangkringan; (iii) Food stalls in New Selo; (iv) Souvenir and food sellers at hiking basecamp.

The DUV of land was IDR 1,301,580,000 which was yielded from 37.5 hectares of cultivated land consisting of nearly $70 \%$ Salacca edulis (snake fruit) plantation (Table 6). Initially, in 1984 the number of farmers was 95 and increased to 120 till now. Salacca edulis was the primary crop combined with coconut, bamboo, and jackfruit. 
Table 6. The DUV of land management in Gunung Merapi National Park, Indonesia

\begin{tabular}{lccc}
\hline Beneficiaries (number of HH) & Land extent (hectares) & Income/month* & Value/years \\
\hline 73 & 0.5 & $1,250,000$ & $766,500,000$ \\
19 & $0.5-1$ & $2,500,000$ & $399,000,000$ \\
3 & $1-3.5$ & $5,400,000$ & $136,080,000$ \\
& & Total & $1,301,580,000$ \\
\hline
\end{tabular}

Note: * nearly $70 \%$ land covered by Salacca edulis plantation. * Incomes from Salacca edulis farmer refer to LAURA 2012

Table 6. The dynamics of pyroclastic flow of Gunung Merapi eruption from 1768-2010

\begin{tabular}{|c|c|c|c|c|c|}
\hline \multirow[b]{2}{*}{ Direction } & \multicolumn{4}{|c|}{ Frequency of eruption* } & \multirow[b]{2}{*}{ Area affected } \\
\hline & $\begin{array}{c}\text { 18th } \\
\text { century }\end{array}$ & $\begin{array}{c}\text { 19th } \\
\text { century }\end{array}$ & $\begin{array}{c}\text { 20th } \\
\text { century }\end{array}$ & $\begin{array}{c}\text { 21th } \\
\text { century }\end{array}$ & \\
\hline Northwest-southwest & 1 & 5 & 13 & 2 & $\begin{array}{l}\text { Tringsing, Senowo, Blongkeng, Batang, Krasak, } \\
\text { Bebeng, Putih, Sat, Lamat }\end{array}$ \\
\hline South-southeast & 1 & 2 & 3 & 2 & Gendol, Woro, Boyong, Bebeng, Kali Adem \\
\hline North & - & - & 2 & 1 & Apu, Jrakah \\
\hline East & - & - & - & - & \\
\hline
\end{tabular}

Note: *The frequency of eruption written in this table is only eruption that has information of the direction of pyroclastic flow. Source: processed from Voight et al. (2000); Sumarti et al. (2014)

The DUV of fuelwood in GMNP was IDR $3,139,200,000$ which was generated from 156,960 bunches of fuelwood. Families that accessed for fuelwood was 1,635 households spread in all flanks of GMNP. They collected the fuelwood two to three times a week. The price of a bunch of fuelwood was IDR 20,000. The DUV of orchids was IDR 9,250,000. This program was conducted by the GMNP authority and communities to reintroduce orchids originally from Merapi volcano into its habitat. There was an involvement of public awareness to fund this program in which up to 2018, there were 22 orchid adopters.

\section{Factors influencing communities' dependence toward GMNP}

Merapi volcano as national park is life support for the people who live on the slopes of the area. Their dependence both economically and socio-culturally has been occurred from generation to generation (Pranowo 1985; Kuswijayanti 2007; LAURA 2012). This study revealed that communities living adjacent to GMNP were influenced by several factors, including the dynamics of eruption, changes in forest function and market conditions. Human dependence toward GMNP influenced by the three factors above was in the form of direct use of its natural resources including grasses/animal fodder, sand mining, water consumption, fuelwood, land for cultivation, tourism and orchid conservation. Illegal activities such as animal hunting and charcoal production were likely sporadic activities that difficult to identify during this research. While cultural activities as an option value is not the objective of this study.

\section{The dynamics of eruption}

Since the $18^{\text {th }}$ Century, Merapi volcano has erupted more than 50 times. There were at least five big eruptions with Volcano Explosion Index (VEI) of 3 (i.e. 1768, 1822, 1849, 1930 and 1960), while eruption with VEI 4 occurred in 1872 and 2010 (Subandriyo et al. 2014). Across these eruptions, the direction and distance of pyroclastic flow always change. In each eruption, the pyroclastic flow, which characterizes the eruption of Merapi volcano, can destroy forests, settlements, and infrastructure in a particular part of Merapi volcano. This situation changed the ecosystem and people's lives partially. Throughout history of Merapi eruption, the directions of pyroclastic flow were toward north, northwest, west, southwest, south, southeast but never headed east side. The farthest pyroclastic flow $(20 \mathrm{~km})$ occurred in 1822 toward Kali Batang at western slope with VEI of 4 (Voight et al. 2000) and in 2010 toward Kali Gendol at southeast slope as far as $15 \mathrm{~km}$ with VEI 4. Table 6 shows the dynamics of Merapi eruption.

The history of Merapi eruption in 1768-2010 (Voight et al. 2000 and Sumarti et al. 2014) revealed that Merapi volcano had become an integral part of Javanese people's living surrounding the volcano. Most eruptions occurred in the western slope with VEI of 1-4, while the last major eruption was toward the south and southeast slope. The sub-village communities directly affected by the pyroclastic flow had strong memories of eruption, evacuation, resource destruction, and economic recovery strategies. Western slope communities adapted better in disaster emergency response based on repeated eruption experiences (Muzani et al. 2014). Southern and southeastern slopes communities learned a lot from the big eruption in 2010. Currently, they have better understanding of disaster preparedness and secure economic assets before the disaster. The northern slope was twice passed by pyroclastic flow. Thus, a small number of people especially the older generation, still remember the hazard of eruption and the rise from economic downturn. Pyroclastic flow never leads to the eastern slope, so the communities lack of experience in emergency response to eruptions or strategies to recover from ecosystem damage and economic downturn (Muzani et al. 2014). 
Table 7. Changes in function of state forest around Merapi volcano, Java, Indonesia

\begin{tabular}{|c|c|c|c|c|}
\hline Year & Sleman District & Magelang District & $\begin{array}{c}\text { Boyolali \& Klaten } \\
\text { Districts }\end{array}$ & Source \\
\hline 1905 & - & Forest area & - & $\begin{array}{l}\text { Perhutani : Document and map } \\
\text { "Proces verbaal Grensregeling van het } \\
\text { Wildhoutboschcomplex G. Merapi, } \\
\text { Districten Salam en Moentilan } \\
\text { Afdeeling Magelang Residentie } \\
\text { Kedoe, in Staatablad } 1905 \text { Nu. } 42 \text { " }\end{array}$ \\
\hline 1912 & Forest area & - & - & $\begin{array}{l}\text { BPKH XI: "Document and map } \\
\text { Proces verbaal Grensregeling van de } \\
\text { Reboisatie Gng. Merapi, Districten } \\
\text { Klegoeng-Balong en Kedjambon, } \\
\text { Regenschap Kalasan en Sleman, } \\
\text { Afdeeling Mataram, Residentie } \\
\text { Jogjakarta, 18 Juni 1912". } \\
\text { Pranowo 1985, Dove 1987 }\end{array}$ \\
\hline 1918 & - & - & Forest area & $\begin{array}{l}\text { BPKH XI: Map "Proces verbaal } \\
\text { Grensregeling van de Reboisatie } \\
\text { Goenoeng Merapi, Districten Bojolali } \\
\text { en Ngampel, Afdeeling Bojolali, } \\
\text { Residentie Soerakarta, } 15 \text { Agustus } \\
\text { 1918" }\end{array}$ \\
\hline 1942 & $\begin{array}{l}\text { Forest area managed by Japan } \\
\text { entity named Ringyo Tyuoo } \\
\text { Zimusyo (RTZ) }\end{array}$ & $\begin{array}{l}\text { Forest area } \\
\text { managed by RTZ }\end{array}$ & $\begin{array}{l}\text { Forest area managed } \\
\text { by RTZ }\end{array}$ & Perhutani 2017 \\
\hline 1945 & $\begin{array}{l}\text { Forest area managed by Jawatan } \\
\text { Kehutanan Republik Indonesia }\end{array}$ & $\begin{array}{l}\text { Forest area } \\
\text { managed by JKRI }\end{array}$ & $\begin{array}{l}\text { Forest area managed } \\
\text { by JKRI }\end{array}$ & Perhutani 2017 \\
\hline
\end{tabular}

$1950 \quad 7016$ ha forest area at Special Region of Yogyakarta managed by the provincial government

$1961-$

1972

$1972 \quad 198.5$ ha Nature Reserve Plawangan Turgo and 30 ha Nature Park Plawangan Turgo

$1975 \quad 198.5$ ha of nature reserve and 30 ha Nature Park Plawangan Turgo \& watershed protection forest managed by Special Region of Yogyakarta Forestry Service

1984 Nature Park Plawangan Turgo became 131 ha

$1989 \quad 282.25$ ha of nature reserve and Nature Park Plawangan Turgo and 1146.13 ha of watershed protection forest managed by Special Region of Yogyakarta Forestry Service

2004 Gunung Merapi National Park (GMNP) managed by Yogyakarta Nature Resource Conservation Center Forest (BKSDA

Yogyakarta)

2007 GMNP managed by GMNP authority (Balai Taman Nasional Gunung Merapi/BTNGM)

$\begin{array}{ll}\text { Watershed } & \text { Watershed } \\ \text { protection forest/ } & \text { protection forest/ } \\ \text { Hutan Lindung } & \text { Hutan Lindung } \\ \text { (Perhutani Djawa } & \text { (Perhutani Djawa } \\ \text { Tengah-KPH Kedu } & \text { Tengah-KPH } \\ \text { Utara) } & \text { Surakarta) }\end{array}$

KPH Yogyakarta: Constitution No. 3 (1950) concerning forest management of forest area at Special Region of Yogyakarta Perhutani 2017: Government Regulation No. 17 (1961). In 1961 Perhutani Djawa Tengah was established, then in 1972 Perhutani Djawa Timur and Djawa Tengah became Perum Perhutani

Map of Nature Reserve and Nature Park Plawangan Turgo, 26 October 1972

Minister of Agriculture Decree No. 147/Kpts/Um/8/1975

Minister of Forestry Decree No. 155/Kpts-II/1984 Minister of Forestry Decree No.758/1989

GMNP managed by BKSDA Yogyakarta

GMNP managed by BTNGM
GMNP managed by BKSDA Yogyakarta

GMNP managed by BTNGM

\author{
Minister of Forestry Decree No. \\ 134/Menhut-II/2004; total area 6410 \\ ha
}

Minister of Forestry Decree No. 3627/Menhut-VII/2014; total area 6607.52 ha 
Adaptation as a strategy of survival to environmental changes is carried out by the people who lived on the slopes of Merapi volcano. The direction and scale of the eruption only impact partially of ecosystem and economy of Merapi. The sub-village communities adapt locally to the ecology of volcano that is vulnerable to change. The communities believe that volcano is not only a threat but also defines as a resource of economic and cultural value as a part of their lives. Communities try to adapt to the risks of living in disaster-prone areas while utilizing available resources.

\section{Changes in forest function}

Most of the landscape around Merapi volcano is state forest that was managed by the Dutch imperial (19121942), Japanese (1942-1945), and the Government of the Republic Indonesia since 1945. Merapi volcano has become a national park since 2004. Before established as a national park, the forest in the southern slope of the mountain was mostly functioned as watershed protection forest (Hutan Lindung), partly in the form of a nature reserve and a nature park, which was entirely under the authority of the provincial office, Special Region of Yogyakarta. The forest in the western, northern and eastern slopes was dominated by watershed protection forest and production forest managed by a state-owned forest company (i.e. Perum Perhutani) under Kedu Utara Forest Section and Surakarta Forest Section.
Changing the function of forest area into a national park had caused communities rejection between 2004 and 2007 because of fears of limited access to forest areas. However, the rejections declined along with the increasingly intensive presence of GMNP managers at the site level and changes in the way of communication between officers and the communities. Tapping of pine resin was an activity that had stopped since 2004 as the national park was established, whereas other uses (i.e. collection of grasses/fodder, water consumption, sand mining, land, tourism) still continues with increase or decrease in intensity. This is different with Kizildag National Park (Akyol et al. 2017) in which local communities do not support protection effort of national park for a long time since the first time declared (1969) because of negative perception triggered by the loss of income, change in traditional lifestyle, and also the decisions of national park management for non-sharing policy with the residents.

\section{Market situation}

Market situation affecting livestock farming and sand mining activity on the slopes of Merapi include increasing demand for livestock products in the form of milk and meat, increasing demand for vegetables that only grow well in the highland, increasing demand of sand material for housing and infrastructure development by urban communities (LAURA, 2012). However, livestock farming that depends on the grasses and fodder in Merapi faced limited land and the availability of Merapi sand was getting smaller as the eruption activity has passed for 8 years.
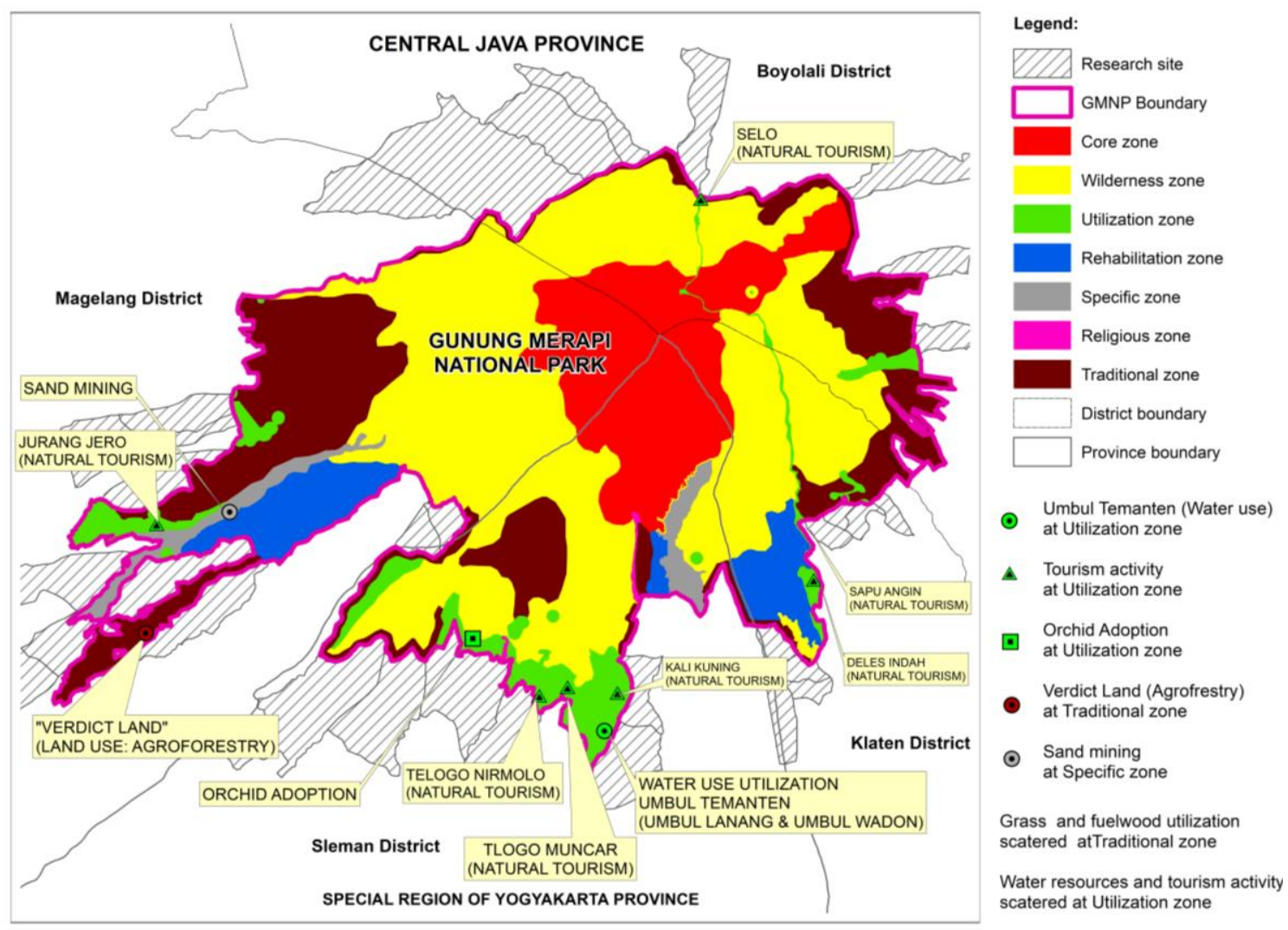

Figure 2. Overlay of zoning map and natural resources utilization at Gunung Merapi National Park, Indonesia 


\section{Characteristic of human dependences toward GMNP}

The relationship between humans and forests in GMNP has long occurred with historical values and dynamics. Each activity reflecting the relationship has ecological and economic adaptation patterns. More recently, the national park gives impacts on the management of Merapi's natural resources, employment, and general income, affecting local economy and lifestyle (Saayman and Saayman 2006). All natural resources from GMNP utilized by sub-vilages community can be seen in Figure 2.

\section{Grass utilization}

Grass utilization on the slopes of Merapi volcano began when Dutch Colonial decided that the Merapi volcano became a forest area in 1912. This change resulted in residents being prohibited from clearing forests and grazing in the forest areas. As a result, there were three changes in the people's lives, i.e. the shifting cultivation system to a permanent farming pattern, the grazing system that was previously released in the forest to be maintained in a stable, and the location of the settlement moved to the lower slope. Since then, the people had to look for grass to feed their livestock (Pranowo 1985; Dove 1987; Triyoga 1991), making grass is a major component of farming and livestock farming until nowadays. Livelihoods in the slopes of Merapi volcano were dominated by farmers (90\%), with the remainder being employees, traders and entrepreneurs.

Families that have livestock reached 4,642 families, consisting of $78 \%$ cattle, $20 \%$ goats, and $2 \%$ rabbits (BTNGM 2017). The farmers who utilizing the grass were dominated by them $45-60$ years old $(43 \%)$, followed by 31 45 years old (38\%), 61-75 years old (13\%) and $15-30$ years old $(5 \%)$. The youngest farmer was 19 years old while the oldest was 75 years old. Livestock ownership was generally passed down to children when they reach adulthood with a production-sharing system, in order to educate responsibility for the sustainability of livestock farming.

Family members were responsible to forage for grasses on a daily basis where they usually did at 5.30 A.M, or alternatively, they did in the afternoon. They generally spent 1-3 hours for the trip to field, which was the biggest allocation of time, while the main activity of foraging for grasses itself took only 30 minutes. half an hour. These entire activities were a social platform for facilitating interactions among communities. People who forage for grasses needed physical strength because they had to walk and carried heavy grasses on their heads and backs. The unity of livestock farming was started from the activities of foraging for grasses then continue when managing the fields like sowing, fertilizing, planting and harvesting in accordance with rotation.

Carrying the grass was traditionally conducted by walking. However, this way was then changed by using motorcycle in 1990 to anticipate the steep and narrow road. Nowadays, only older generation was still walking when carrying the grasses since this was the only possible way to do. People also usually combined manual carriage and motorcycle. Unlike other parts of the slopes, west side is topographically flat so that wheelbarrow was more commonly used. Additional tool like flying fox was used to transport grasses across ravine between two sub-villages in southeast side of GMNP since 2017.

Alang-alang (Imperata cylindrica) that flourishes in the wild was sought intentionally to feed livestock up to 1990. It was then being replaced by Kalanjana (Brachiara mutica) in order to anticipate increased livestock demand and yet limited lands. Brachiara mutica is characterized by high yields and nutrition, which is easy to plant and also thrive on up to an altitude of 1,500 meters above sea level. Rational decision as a strategy to sustain livestock farming was selected by sub-villages communities who live adjacent toward GMNP.

\section{Water utilization}

The relationship between human and water resembles an effort to meet the basic needs of life. Humans search for water sources and then try to bring it closer to settlements. For communities living nearby Merapi volcano, the efforts to find water sources and how to channel water to settlements as well as the management of water sharing among residents had a diverse history. Pyroclastic flow can destroy the infrastructure of water pipelines and reservoirs. The retrieval of water sources after being buried by eruption materials and post-eruption water infrastructure repairs have been carried out several times by the communities, assisted by the government and NGOs.

There were 35 water sources in the form of springs, rivers, and dug wells located in the forest area utilized by 3,369 families (BTNGM 2017). The addition of 12 sources of water that have not been recorded, so that a total of 47 water sources with diverse water discharge (BTNGM 2018). The western and southern parts of GMNP generally have large water discharge. The biggest water discharge was Umbul Temanten located on the southern slope with debit of 793.44 liters per second. Water source Sapu Angin discharge 0.014 lt per second, eastern slope of Tuk Muncar $3.9 \mathrm{lt} / \mathrm{sec}$ (BTNGM 2018). The northern slope did not have a water source so the community must channel water from Merbabu Mountain through pipelines that crossing ravines and roads.

The diversity of internal management system of water utilization groups on the southern slope can be seen in 3 sub-village located at an altitude of 900 meters above sea level, namely Kaliurang Barat, Ngandong and Turgo with each group had different amount of fees and the mechanism of rules. Water management in West Kaliurang was done by installing a water meter at each house with a monthly fee of IDR10,000 (except residents who have commercial businesses). In Ngandong sub-village, which is adjacent to the Krasak River, had a large water discharge. The construction of water installations from water sources to settlements was assisted by the government after the 2010 eruption. The water meters had not yet been installed in residents' homes, but group leaders continued to call for wise use of water even though the availability of water was able to meet the needs of 8 sub-villages. Ngandong citizens have to pay IDR 10,000 per year for pipeline maintenance. 
Turgo sub-village obtained water from 3 water sources namely Siraman Lanang, Siraman Wadon, and Tuk Candi. Water management was carried out with initial fees for new users at different rates between local people and migrants. In this village, each house had a water container with a monthly fee of IDR 20,000.

Commercial water use was sourced from Umbul Temanten, Umbulharjo village, Cangkringan Sub-district, Sleman District. Umbul Lanang infrastructure was built in 1923 with a debit of 100 liters/second to serve the needs of clean water in the city of Yogyakarta. After independence, the piped water network from Umbul Lanang to the city of Yogyakarta was managed by Tepas Tirto Marto as the forerunner to the Yogyakarta City Tirtamarta PDAM (PDAM Tirtamarta Yogyakarta). Eruption activity in 1930 caused severe damage to water utilization infrastructure in Umbul Lanang. Rehabilitation of the Umbul Lanang source was completed and put into operation in 1936. The damage occurred again in the 1960s and was overcome by the construction of shallow wells, gravity wells, and water treatment plants. The water catching building in Umbul Wadon was built in 1986 by PDAM Tirtamarta Yogyakarta so that the party that pioneered the utilization of Umbul Temanten water (PDAM Tirtamarta Yogyakarta). PDAM Sleman and PT. AMI has been using Umbul Wadon water since the 1990s. There were three private companies that used water commercially in Umbul Temanten. The communication process between GMNP and PDAM is still in the stage to align the understanding of licensing authority and the procedure for water utilization permits. On the other hand, PT AMI is currently proposing a permit process to the Ministry of Environment and Forestry.

\section{Sand mining}

The utilization of sand materials from Merapi volcano is inseparable from the history of eruption and the secondary impact of eruption, namely lahar. Mining production cycles usually begin with eruptive activity which causes an abundant supply of materials (LAURA 2012) followed by cold lava events. Cold lava is a mixture of volcanic materials and water that flows swiftly (more than normal flow conditions) from the eruption of a volcano that moves from upstream to downstream (Lavigne and Thouret 2003). Lava that occurred in the river channel in 2010 was post-eruptive lava, meaning that it deposited after the eruption. About $70 \%$ of post-eruptive lahars occurred in the Progo watershed in the western slope and the remaining $30 \%$ occurred in the Opak watershed in southern slope (Belizal et al. 2013). The main factors causing the location of cold lava occurrences are: (i) rainfall, in which it had $4124 \mathrm{~mm}$ in the west slope and $2000 \mathrm{~mm}$ in south slope; and (ii) material of 20 million $\mathrm{m}^{3}$ which was deposited on the western slope due to the influence of wind during eruption (Surono et al. 2012).

The sand mining location was an intermediate river, meaning that it basically dry river type but when raining in the upstream, the rainwater along with lava will flow downstream. This research focused on mining sites within the forest area, Sungai Putih. Sungai Putih is a river that had been often traversed by lava from 1782 to 2010 . The largest lava event occurred in 1969 and 2010. The frequency of lava events in 2010-2011 was high, namely 55 events with an average occurrence 2 times a week during the rainy season (Belizal et al. 2013). The location of sand mining in the Merapi forest area involved large number of local communities and a long period of time occurred within the Sungai Putih flow, better known as Jero Jurang. Over time, when sand material began to decrease, miners searched for the sand getting deeper into the forest area, dug deeper into the sand to form a niche, and even took sand on the river bank.

Of 220 trucks belonging to the group of Paguyuban Merapi Hijau, not all members did sand mining every day due to vehicle damage or personal interests of the truck owners. The average number of trucks that did sand mining was 133 trucks per day with 700-800 laborers. Generally, a group of sand miners consisted of 5 people who serve as sand diggers, sieves, collectors and transporters to load sand into the truck. The price to pay by truck drivers to buy sand reached IDR 450,000-IDR 550,000 with additional costs of IDR 100,000 for truckloads, and IDR 100,000 for spare parts and repairs, resulting in the total cost of IDR 750,000 . This sand was then sold in depots around the area for IDR 1,050,000 (IDR 130,000 per cubic meter), resulting in profit obtained by the driver and owner of the truck of IDR 300,000-350,000 per trip. When the research was conducted, the sand mining activity was halted by the GMNP authority because it violated the rules by doing mining on the river bank.

\section{Natural tourism activities}

Human relationship to GMNP in the form of ecotourism activities was dominated by GMNP authority from 7 tourist entrances. The economic value received by the GMNP authority was in the form of non-tax state income (Penerimaan Negara Bukan Pajak/PNBP) while for local communities was tourist guiding and managing climbing basecamp. Other activities including buying and selling food, souvenirs and vehicle services were all outside the park but their existences were directly influenced by GMNP's policies and Merapi volcano's activities. Tourism activities inside the park in the utilization zone were located in seven places which can be divided into two types of management: (i) sole management by GMNP authority in three locations (i.e. Telogo Muncar, Telogo Nirmolo, Deles Indah) and (ii) joint management between GMNP authority and communities in four locations (i.e. Kalikuning, Jero Jurang, Sapu Angin and Selo).

The direct economic benefits of ecotourism have been supporting the communities in Kaliurang Barat sub-village since the 1980s. The business of selling food and souvenirs for more than 30 years is a reflection of the economic benefits obtained by residents which are able to meet their basic daily needs. In addition to selling food and souvenirs, there is a growing business of vehicle services in the form of Jeep Lava Tour which has been increasing since the beginning of 2012. The tour began when many tourists were interested to see the impacts of the 2010 eruption, but they could not reach the location due to heavy terrain. 
Seeing this opportunity, the community offered jeep vehicles to reach the affected areas. Tourist attractions, namely my treasure museum (i.e. remnants of houses affected by heavy eruptions showing the damages, household tools and photographs), Kaliadem bunkers (i.e. hiding places to avoid the hazards of eruption), alien rocks (i.e. a stone depicted alien face as a photo spot for traveler) and the house of the late Mbah Maridjan (i.e. the most prominent figure serving as caretaker of Mount Merapi who died due to the eruption in 2010).

Jeep communities currently have grown to 29 groups with a total of 960 vehicles (an increase of 100 jeeps every year since 2012-2018). This unique transportation service provided a very tangible economic benefit that increased the income of the community. Jeep lava tour vehicle service business is inseparable from the impact of Merapi eruption in 2010, meaning that the 2010 eruption actually delivered a tourism opportunity as an economic alternative. It has now become a major economic source as an effort to rise from the economic downturn local residents which is carried out by Pelemsari, Pangukrejo, West Kaliurang and East Kaliurang sub-villages. The development of the jeep tour shows significant impact of the existence of the national park to local economy in the form of income generation and employment opportunities, like in the Addo Elephant National Park, South Africa (Saayman and Saayman 2006).

\section{Fuelwood utilization}

The use of fuelwood began when humans lived on the slopes of Merapi volcano. Fuelwood was obtained from branches, twigs and some tree trunks. The communities used fuelwood for household needs, livestock needs (a mixture of cattle feed using warm water) and a small portion was sold. The collection of fuelwood was done 2-3 times a week throughout the year with an unspecified time. Fuelwood was still used for cooking and warming the body in the kitchen of villagers at an altitude of 1300 meters above sea level. The introduction of gas stoves and biogas machines, as well as awareness from the staff of the national park, had prevented the communities against tree felling, resulting in fuelwood uses in the last five years.

\section{Land use}

Land use by the people of Ngablak (i.e. Salamsari, Jengglik, Srikaton) sub-villages in Srumbung sub-district within the forest state had occurred since the era of Perum Perhutani. Land disputes between the communities and the government occurred in the early 1980s. The case ended in a Magelang District Court ruling in 1982 which stated that the state-owned forest area was allowed to be accessed by the communities. This land then became famous as "verdict land". Over a period of 30 years, there had been an indication of expansion. Now, total of the verdict land has reached 37.5 hectares. In GMNP, this land becomes the longest and the most complicated problem to resolve. A joint mapping in 2012 received subtle resentment by avoiding officers, due to fears of loss access to the land. A softer approach through joint dialogue finally reached an agreement at the end of 2018 with joint mapping to identify locations and names of farmers allowed to plant species. Also, the agreement stated that there is no land expansion and fraud. In addition to the verdict land, there is still an area of approximately 40 hectares that is accessed by the community for agroforestry. The existence of this land is still not well identified and mapped because there is not yet common understanding between the GMPN authority and the community.

\section{Orchid's adoption}

The orchid adoption program was a GMNP authority effort to preserve Merapi's native orchids in their habitat as well as to improve the welfare of community. The orchid adoption program began in 2015 through a joint dialogue process. Adoption of orchids invited public to contribute as adopters. The orchids adopted came from the group, then were reintroduced in the forest and treated for 3 years in the mother tree. However, this program is not routinely conducted.

In conclusion, this study found that the Direct Use Value (DUV) of Gunung Merapi National Park (GMNP) was IDR $87,947,589,505$ year $^{-1}$, dominated by grass utilization for livestock, sand mining and water consumption with took $93.29 \%$ of the total value for the three resources. GMNP have diverse relationships with humans who live adjacent to the forest boundary and dependence to forest. Local communities used resources generated from Merapi volcano for their economic needs and also as part of their social life. The higher DUV, the community dependence is also getting stronger because the resources were inseparable from daily life at the slopes of Merapi volcano. Communities' activities have occurred from generations, reflecting human adaptation to the dynamics of eruptions, changes in legal status of the forest and market situations. The communities living in the subvillages around GMNP are a subsystem of Merapi volcano ecosystem, so their existence cannot be ignored. The reciprocal relationships between natural and social systems are important aspect for the national park authority because forest areas and local communities (sub-villages) are an integral unit of ecosystem. As such, positioning the subvillage communities as partners for GMNP authority becomes very important. Based on the findings of this study and referring to protected areas matrix stated by IUCN (2015), Gunung Merapi National Park should be classified as protected area category II (a national park) and $\mathrm{B}$ (with shared governance/collaborative management).

\section{ACKNOWLEDGEMENTS}

We thank people of sub-villages adjacent to GMNP for their contribution as respondents and key informants. Moreover, we are thankful to Ministry of Environment and Forestry for the funding for this research, IPB University, GMNP authority and Center of Volcanology a Geological Hazard Mitigation for facilities and supporting data. Great thanks to other parties who cannot be mentioned personally for giving us their help to accomplish this work. 


\section{REFERENCES}

Akyol A, Türkoğlu T, Bekiroğlu S, Tolunay A. 2017. Resident perceptions of livelihood impacts arising from Kizildag National Park, Turkey. Environ Dev Sustain 20: 1037-1052.

Anna Z, Saputra DS. 2017. Economic valuation of whale shark tourism in Cenderawasih Bay National Park, Papua, Indonesia. Biodiversitas 18: 1026-1034.

Belizal E, Lavigne F, Hadmoko DS, Degeai JP, Dipayana GA, Mutaqin BW, Marfai MA, Coquet M, Le Mauff B, Robin AK, Vidal C, Cholik N, Aisyah N. 2013. Rain-triggered lahars following the 2010 eruption of Merapi volcano, Indonesia: A major risk. J Volcanology Geothermal Res 261: 330-347.

Berkes F. 2017. Environmental governance for the Anthropocene? Socialecological system, resilience, and collaborative learning. Sustainability 9 (1232): 1-12.

BPKH [Balai Pemantapan Kawasan Hutan Wilayah XI Yogyakarta] 1912. Document and map: Proces verbaal Grensregeling van de Reboisatie Gng. Merapi, Districten Klegoeng-Balong en Kedjambon, Regenschap Kalasan en Sleman, Afdeeling Mataram, Residentie Jogjakarta, 18 Juni 1912. [Indonesian]

BPKH [Balai Pemantapan Kawasan Hutan Wilayah XI Yogyakarta] 1918. Map: Proces verbaal Grensregeling van de Reboisatie Goenoeng Merapi, Districten Bojolali en Ngampel, Afdeeling Bojolali, Residentie Soerakarta, 15 Agustus 1918. [Indonesian]

BTNGM [Balai Taman Nasional Gunung Merapi]. 2017. Rencana Induk Pemberdayaan Masyarakat Desa Penyangga Taman Nasional Gunung Merapi. BTNGM, Yogyakarta. [Indonesian]

BTNGM [Balai Taman Nasional Gunung Merapi]. 2018. Laporan Kegiatan Monitoring Sumber Daya Air. BTNGM, Yogyakarta. [Indonesian]

Budiharta S, Meijaard E, Wells JA, Abram NK, Wilson KA. 2016) Enhancing feasibility: Incorporating a socio-ecological systems framework into restoration planning. Environ Sci Policy 64, 83-92.

Daily GC, Polasky S, Goldstein J, Kareiva PM, Mooney HA, Pejchar L, Ricketts TH, Salzman J, Shallenberger R. 2009. Ecosystem services in decision making: time to deliver. Front Ecol Environ 7: 21-28.

Dharmawan AH. 2007. Dinamika sosio-ekologi pedesaan: perspektif dan pertautan keilmuan ekologi manusia, sosiologi lingkungan dan ekologi politik. Jurnal Sodality 1: 1-40. [Indonesian]

Dewanta AS. 2010. Valuation of Mount Merapi National Park: A travel cost analysis. Econ J Emerg Market 2: 79-88.

Dove MR.1987. Kepercayaan Tentang Alang-Alang, in Manusia dan Alang-Alang di Indonesia. Dove MR and Martopp S (eds). Gadjah M University Press, Yogyakarta [Indonesian]

Folke C, Colding J, Berkes F. 2003. Synthesis: Building Resilience and Adaptive Capacity in Social-Ecological System. In: Berkes F, Colding J, Folke C (eds) Navigating Social-Ecological Systems, Building Resilience for Complexity and Change. Cambridge University Press, Cambridge.

Helida A, Zuhud EAM, Hardjanto, Purwanto Y, Hikmat A. 2015. The ethnography of Kerinci. Intl $\mathbf{J}$ Indonesian Soc Cult. Komunitas 7 : 283-296.

Hudayana B. 1994. Adaptasi Masyarakat Terhadap Bencana Alam, Stud Kasus Bencana Alam Merapi. Fakultas Sastra Universitas Gadjah Mada, Yogyakarta. [Indonesian]

Iskandar J, Iskandar BS, Partasasmita R. 2016. Responses to environmental and socio-economic changes in the Karangwang traditional agroforestry system, South Cianjur, West Java. Biodiversitas 17: 332-341.

Iskandar BS, Iskandar J, Wibawa HA, Partasasmita R. 2017. Farmers and tumpangsari: Case study in Palintang Hamlet, Cipanjalu Village, Bandung, Indonesia. Biodiversitas 18: 1135-1149.

IUCN [International Union for Conservation of Nature and Natura Resources, World Commission on Protected Areas]. 2004. Guidelines for Planning and Managing Mountain Protected Areas. Hamilton, Lawrence, McMillan, Linda (eds.). IUCN, Gland, Switzerland and Cambridge.

IUCN [International Union for Conservation of Nature and Natura Resources]. 2015. Protected area governance and management. Worboys GL, Lockwood M, Kothari A, Feary A, Pulsford I (eds). ANU Press, Canberra.

Ives JD, Messerli B, Spiess E. 2004. Mountains of the world: a global priorities. In: Messerli B, Ives JD (eds.) Mountains of The World: A Global Priority. Parthenon, New York.
Kuswijayanti ER, Darmawan AH, Kartodihardjo H. 2007. Krisis-krisis sosio-Politico-ecology di kawasan konservasi: Studi ekologi politik di Taman Nasional Gunung Merapi. Soladity: Jurnal Transdisiplin Sosiologi, Komunikasi dan Ekologi Manusia: 41-66. [Indonesian]

LAURA [Laboratorium Antropologi untuk Riset dan Aksi Universitas Gadjah Mada]. 2012. Komunitas Lereng Merapi Serta Respon Terhadap Erupsi Merapi 2010. Laboratorium Antropologi untuk Riset dan Aksi Universitas Gadjah Mada, Yogyakarta. [Indonesian]

Lavigne F, De Coster B, Juvin N, Flexier F, Morin J, Sartohadi J. 2008. People's behavior in the face of vulcanic hazards: Perspective from Javanese communities, Indonesia. J Volcanology Geothermal Res 172: $273-287$

Lavigne F, Thouret JC. 2003. Sediment transportation and deposition by rain-triggered lahars at Merapi Volcano, Central Java, Indonesia. Geomorphology 49 (1-2): 45-69.

Marten GG. 2001. Human Ecology: Basic Concept of Sustainable Development. Earthscan, London.

McNeely JA. 1994. Protected areas for 21 st century: working to provide benefits to society. Biodivers Conserv 3: 390-405

Newton P, Miller DC, Ateenyi MA, Byenkya, Agrawal A. 2016. Who are forest-dependent people? A taxonomy to aid livelihood and land-use decision-making in forest regions. Land Use Policy 57: 388-395.

Pearce D, Moran D. 1994. The Economic Value of Biodiversity. IUCNEarthscan, London.

Pearce DW. 2001. The economic value of forest ecosystems. Ecosyst Health 7: 21-28.

Perum Perhutani. 2017. Sejarah Perusahaan. /www.bumn.go.id/perhutani/halaman/47. [Indonesian]

Pranowo DS, Handojo Adi. 1985. Manusia dan Hutan: Proses Perubahan Ekologi di Lereng Gunung Merapi. Gadjah Mada University Press, Yogyakarta. [Indonesian]

Pratt DJ, Preston L. 1998. The economics of mountain resource flow, Unasylva 49 (4): $31-38$

Rambo AT. 1983. Conceptual Approaches to Human Ecology. East-West Environment and Policy Institute, Hawai'i, USA

Rizal A, Dewanti LP. 2017. Using economic values to evaluate management options for fish biodiversity in the Sikakap Strait, Indonesia. Biodiversitas 18: 575-581.

Roslinda E, Kartikawati SM, Rabudin. 2017. Economic valuation for Tembawang ecosystem, in Sebangau District West Kalimantan, Indonesia. Biodiversitas 18: 1506-1516.

Roslinda E. 2019. Economic valuation of Danau Sentarum National Park, West Kalimantan, Indonesia. Biodiversitas 20: 1983-1989.

Saayman M, Saayman A. 2006. Creating a framework to determine the socio-economic impact of national parks in South Africa: a case study of the Addo Elephant National Park. Tourism Economic 12: 619633.

Setiyani AD, de Fraitur C, Susanto RH, Duker A. 2017. Economic valuation for water supply from Merapi Volcano National Park (Case Study: Kali Kuning Sub Watersheed). Jurnal Pengelolaan Sumberdaya Alam dan Lingkungan 7: 29-36. [Indonesian]

Subandriyo. Santosa AG, Sumarti S, Aisyah N, 2014. Hasil Pemantauan Aktivitas G. Merapi: Dasar Peringatan Dini Erupsi Besar 2010. In: Erupsi Gunung Api Merapi 2010. Pemantauan, Penanggulangan dan Peran Masyarakat. Pusat Vulkalogi dan Mitigasi Bencana Geologi, Balai Penyelidikan dan Pengembangan Teknologi Kebencanaan Geologi, Yogyakarta. [Indonesian]

Sumarti S, Subandriyo, Sayudi DS, Aisyah N, Muzani, Cholik N, Djalai Y. 2014. Peta Kawasan Rawan Bencana G. Merapi Pasca Erupsi Eksplosif 2010. In: Erupsi Gunung Api Merapi 2010. Pemantauan, Penanggulangan dan Peran Masyarakat. Pusat Vulkalogi dan Mitigasi Bencana Geologi, Balai Penyelidikan dan Pengembangan Teknologi Kebencanaan Geologi, Yogyakarta. [Indonesian]

Surono M, Jousset P, Pallister J, Boichu M, Fabrizia M, Buongiorno, Budisantoso A, Rodriguez FC, Andreastuti S, Prata F, Scneider D. 2012. The 2010 explosive eruption of Java's Merapi Volcano-a 100 year event. J Volcanol Geotherm Res 100: 121-135.

Thouret JC, Lavigne F, Kelfoun K, Bronto S. 2000. Toward a revised hazard assessment at Merapi volcano, Central Java. J Volcanol Geotherm Res 100: 479-502.

Triyoga LS. 1991. Manusia Jawa dan Gunung Merapi: Persepsi dan Kepercayaannya. Gadjah Mada University Press, Yogyakarta. [Indonesian]

Triyoga LS. 2010. Merapi dan Orang Jawa. Persepsi dan Kepercayaan. Gramedia Widisarana Indonesia, Jakarta. [Indonesian] 
Turner K, Georgiou S, Clark R, Brouwer R. 2004. Economic valuation of water resources in agriculture. From the sectoral to a functional perspective of natural resource management. FAO, Rome.

Voight B, Sukhyar R, Wirakusumah AD. 2000. Introduction to the special issue on Merapi Volcano. J Volcanol Geotherm Res 100: 1-8.
Widada. 2004. Nilai Manfaat Ekonomi dan Pemanfaatan Taman Nasional Gunung Halimun bagi Masyarakat. [Disertation]. IPB University, Bogor. [Indonesian] 